\title{
PERLAKUAN INVIGORASI PADA BENIH PADI DI KELOMPOK TANI PELITA DESA NOEPESU
}

\author{
Anna Tefa \\ Program Studi Agroteknologi, Fakultas Pertanian, \\ Universitas Timor, Indonesia \\ Pos-el: annatefa@gmail.com
}

Dikirim: 4 Juli 2018

Direvisi: 12 Agustus 2018

Diterbitkan: 29 Agustus 2018

\begin{abstract}
Abstrak
Penyimpanan benih dapat mengakibatkan turunnya kemampuan benih untuk menjadi bibit yang vigor. Salah satu cara yang dapat dilakukan sebelum tanam untuk memperbaiki performa benih adalah perlakuan invigorasi dengan matriconditioning (conditioning dengan menggunakan media padat lembab) pada benih. Tujuan pengabdian ini adalah petani mitra menguasai vigor dan viabilitas benih yang digunakan untuk pembibitan, mitra dapat mengetahui dan mampu melakukan invigorasi pada benih padi untuk meningkatkan daya berkecambah, kecepatan pertumbuhan, keserempakan tumbuh dan mengurangi benih yang tumbuh abnormal pada saat persemaian. Penelitian ini dilaksanakan di kelompok Tani Pelita Desa Noepesu Kabupaten Timor Tengah Utara dengan metode pelatihan dan praktek langsung di Lahan sawah petani. Hasil yang diperoleh menunjukkan bahwa animo masyarakat untuk mengikuti pelatihan ini sangat besar. Benih padi yang digunakan untuk persemaian tumbuh lebih cepat yaitu 5 hari setelah semai sudah tumbuh normal, pertumbuhannya seragam dan memiliki daya berkecambah yang tinggi.
\end{abstract}

Kata kunci : benih, padi, invigorasi

\section{Abstract}

Seed storage can result in a decrease in the ability of seeds to become vigorous seeds. One way that can be done before planting to improve seed performance is the invigorating treatment with matriconditioning (conditioning using moist solid media) on the seed. The purpose of this service is that partner farmers master the vigor and viability of seeds used for nurseries, partners can know and are able to invigorate rice seeds to increase germination, speed of growth, simultaneous growth and reduce seeds that grow abnormally during seeding. This study was carried out in the Kelompok Tani Pelita District Noepesu with training methods and direct practice in farmers' rice fields. The results obtained show that the public interest in joining this training is very large. 
Rice seeds used for seedling grow faster, 5 days after the seedlings have grown normally, the growth is uniform and has high germination.

Key words: seeds, rice, invigoration

\section{PENDAHULUAN}

Mitra yaitu Kelompok Tani Pelita Desa Noepesu, Kecamatan Miomaffo Barat Kabupaten Timor Tengah Utara, Propinsi Nusa Tenggara Timur. Desa ini terletak di bawah kaki Gunung Mutis yang merupakan salah satu gunung tertinggi di Pulau Timor dan berbatasan dengan Kabupaten Timor Tengah Selatan. Mata pencaharian utama penduduk di desa ini adalah bertani dan beternak. Padi dan jagung adalah tanaman pokok yang menjadi andalan bagi masyarakat di Desa Noepesu. Saat masa tanam padi tiba, salah satu masalah yang mereka hadapi adalah benih yang digunakan tidak seragam pertumbuhannya bahkan waktu untuk berkecambah semakin panjang antara 1-2 minggu, padalah benih padi yang memiliki vigor tinggi sudah bisa berkecambah normal pada 5 hari setelah semai.

Benih yang telah mengalami kemunduran dapat diberikan perlakuan (treatment) berupa invigorasi untuk meningkatkan kembali performa suatu benih. Menurut Sadjad et.al (1999), benih yang mengalami penundaan tanam terkadang dibiarkan dalam kondisi yang tidak optimal, misalnya ditempatkan di ruangan yang tidak optimum, dalam kemasan yang terbuka atau sebelum dibawa ke lapangan ditempatkan di ruangan yang berkelembaban udara tinggi. Hal terrsebut akan menyebabkan benih mengalami penurunan vigor yang cepat sehingga waktu ditanam vigor kekuatan tumbuh sudah rendah. Robi'in (2007) menyatakan bahwa benih padi yang disimpan dalam ruangan terbuka cepat mengalami kemunduran mutu (daya kecambah rendah) akibat fluktuasi suhu dan kelembaban selama penyimpanan. Salah satu periode kritis dalam siklus kehidupan tanaman ialah waktu antara benih mulai ditanam dengan munculnya kecambah, karena pada saat tersebut benih dihadapkan pada beragam kondisi lingkungan tumbuh yang berpengaruh terhadap munculnya kecambah serta vigor kecambah. Menurut Taylor et al. (1998), seed enhancement dapat didefinisikan sebagai perlakuan pasca panen yang dapat memperbaiki perkecambahan atau pertumbuhan kecambah atau memfasilitasi benih, dan materi lain yang diperlukan saat tanam. Definisi tersebut mencakup tiga metode umum, yaitu (1) pre-sowing hydration treatment atau priming (invigorasi), (2) teknologi coating, dan (3) seed conditioning. Invigorasi (priming) benih merupakan perlakuan yang diberikan terhadap benih 
sebelum penanaman dengan tujuan memperbaiki pertumbuhan dan kecambah. Beberapa perlakuan invigorasi benih juga digunakan untuk menyeragamkan pertumbuhan kecambah dan meningkatkan laju pertumbuhan kecambah (Arief dan Koes 2010). Ilyas (2012) menambahkan invigorasi merupakan suatu proses yang dilakukan untuk meningkatkan vigor benih yang telah mengalami deteriorasi atau kemunduran.

Metode matriconditioning merupakan proses pengimbibisian benih secara terkontrol. Benih, air, dan bahan matrik merupakan tiga komponen utama untuk matriconditioning. Air yang digunakan untuk mengimbibisi dicampurkan secara merata ke benih dan bahan matrik, tetapi karena adanya bahan matrik air sebagian besar terikat di bahan matrik. Benih akan mengimbibisi air yang bercampur dengan bahan matrik hingga terjadi titik keseimbangan. Potensial air dari sekitar bahan matrik ditentukan oleh sifat fisik dan sifat kimia bahan matrik. Persyaratan media matriconditioning yang akan digunakan antara lain mempunyai potensial matrik tinggi dan potensial osmotik dapat diabaikan, daya larut dalam air rendah dan tetap utuh selama perlakuan, bahan inert tidak beracun, kapasitas daya pegang air tinggi, tetap kering dan tidak berserbuk, ukuran partikel, struktur dan daya serapnya seragam, luas permukaan besar, dan berkemampuan melekat pada permukaan benih (Khan 1992). Benih yang diberi perlakuan matriconditioning umumnya masih memiliki daya berkecambah, jika benih sudah mati maka teknik invigorasi dengan matriconditioning tidak menunjukkan hasil yang nyata. Mekanisme terjadinya invigorasi ini dapat didekati melalui proses imbibisi yang terkontrol melalui media carrier padat seperti bubuk arang sekam yang diintegrasikan untuk meningkatkan viabilitas dan vigor benih serta memecahkan permasalahan dormasi fisiologi pada benih padi.

Kreativitas petani akhir-akhir ini mengalami peningkatan yaitu dengan melakukan usaha penjualan bibit padi. Terkadang mereka mengalami kendala karena benih padi yang sudah disimpan cukup lama akan menurun viabilitasnya jika ditanam kembali sehingga akan menghasilkan kecambah yang pertumbuhannya lambat dan abnormal. Beberapa petani menggeluti usaha penjualan bibit padi jika memasuki musim tanam. Sehubungan dengan usaha penjualan bibit, salah satu kendala yang dihadapi adalah benih memiliki vigor rendah yang berakibat terjadinya penurunan kecepatan perkecambahan benih dan meningkatnya jumlah kecambah abnormal. Akibatnya petani mengalami kerugian akibat benih yang digunakan menurun viabilitasnya. 
Terkadang, permintaan dari petani pembeli bibit tidak dapat terpenuhi karena kondisi bibit yang kurang baik pertumbuhannya.

Penelitian yang dilakukan oleh Arief dan Saenong (2006), menunjukkan bahwa pertumbuhan padi yang lambat dan hasil yang rendah disebabkan oleh penggunaan bibit yang sudah mengalami penurunan mutu meskipun daya berkecambahnya relatif tinggi. Disamping usaha penjualan bibit padi, petani mitra juga dapat menggunakan metode ini untuk meningkatkan produksi padi di lahan mitra sendiri. Selain itu, mitra juga bisa memanfaatkan sekam padi untuk membuat arang sekam. Penggunaan arang sekam untuk matriconditioning pada benih padi merupakan salah satu alternatif yang bisa diterapkan kepada mitra untuk meningkatkan usaha penjualan bibit padi.

\section{METODE}

Kegiatan invigorasi pada benih padi berupa pelatihan dan paraktek langsung di lahan petani. Kegiatan yang dilaksanakan di sawah ini diikuti oleh sedikitnya 12 orang. Mereka mengatakan bahwa selama ini belum ada petugas atau penyuluh yang mengajarkan mereka tentang perlakuan invigorasi untuk benih padi. Upaya peningkatan produksi dan produktivitas pertanian padi memerlukan suplai benih unggul dan bermutu, ditinjau dari aspek fisik, fisiologis dan genetika. Benih padi yang telah disimpan lama selama kurun waktu beberapa bulan dengan kondisi suhu dan kelembaban ruang simpan yang tidak terkontrol akan berpengaruh terhadap percepatan penurunan viabilitas dan vigornya. Upaya meningkatkan viabilitas dan vigor benih salah satunya melalui perlakuan invigorasi dengan perlakuan matriconditioning (Koes et al. 2011). Pada hakikatnya vigor benih harus relevan dengan tingkat produksi, artinya dari benih yang bervigor tinggi akan dapat dicapai tingkat produksi yang tinggi. Vigor benih yang tinggi dicirikan antara lain tahan disimpan lama, tahan terhadap serangan hama dan penyakit, cepat dan merata pertumbuhannya serta mampu menghasilkan tanaman dewasa yang normal dan berproduksi baik dalam keadaan lingkungan tumbuh yang suboptimum.

Kemunduran suatu benih dapat diterangkan sebagai turunnya kualitas atau viabilitas benih yang mengakibatkan rendahnya pertumbuhan tanaman serta produksinya, dimana kejadian tersebut merupakan suatu proses yang tidak dapat balik dari kualitas suatu benih. Benih yang memiliki vigor rendah akan berakibat terjadinya kemunduran yang cepat selama penyimpanan, makin sempitnya keadaan lingkungan 
dimana benih dapat tumbuh, kecepatan berkecambah benih menurun, kepekaan akan serangan hama dan penyakit meningkat, meningkatnya jumlah kecambah abnormal dan rendahnya produksi tanaman (Sadjad, 1993).

Aplikasi perlakuan matriconditioning yang diterapkan oleh kelompok mitra pengabdian, dapat menggunakan arang sekam. Dalam pelaksanaan program ini, menggunakan metode penyuluhan, tanya jawab, diskusi, penugasan dan praktek langsung.

Tabel 1. Alur Kegiatan dan Partisipasi Mitra Pengabdian

\begin{tabular}{|c|l|l|}
\hline No. & \multicolumn{1}{|c|}{ Kegiatan } & \multicolumn{1}{|c|}{ Partisipasi Mitra } \\
\hline 1 & $\begin{array}{l}\text { Penyuluhan dan bimbingan tentang } \\
\text { teknik matriconditioning pada benih } \\
\text { padi, meliputi pengertian, penjelasan dan } \\
\text { tujuan perlakuan matriconditioning. }\end{array}$ & $\begin{array}{l}\text { Berperan aktif sebagai peserta, } \\
\text { dengan mendengarkan penjelasan, } \\
\text { melakukan diskusi dan tanya jawab }\end{array}$ \\
\hline 2 & $\begin{array}{l}\text { Pelatihan aplikasi matriconditioning } \\
\text { secara individu maupun kolektif sesuai } \\
\text { bagan kegiatan. }\end{array}$ & $\begin{array}{l}\text { Berpartisispasi aktif dengan } \\
\text { penyiapan alat dan bahan serta } \\
\text { praktek langsung ke lahan } \\
\text { persemaian. }\end{array}$ \\
\hline
\end{tabular}

Perlakuan matriconditioning pada benih padi adalah mencampur benih padi dengan bubuk arang sekam yang sudah diayak dengan ukuran 0,5 mesh dan rhizobakteri dengan perbandingan antara benih : media : rhizobakteri adalah $1: 0,8$ : 1,2. Bubuk arang sekam dan rhizobakteri diaduk rata, kemudian benih dimasukkan dan diaduk kembali sampai seluruh permukaan benih diselimuti media arang sekam, kemudian dimasukkan dalam gelas/toples kaca dan ditutup dengan plastik bening yang telah diberi beberapa lubang, dan disimpan selama 30 jam ( 1 jam sebelum radicula muncul). Benih hasil perlakuan matriconditioning dibersihkan dan siap dikecambahkan di tempat persemaian (Gambar 1).
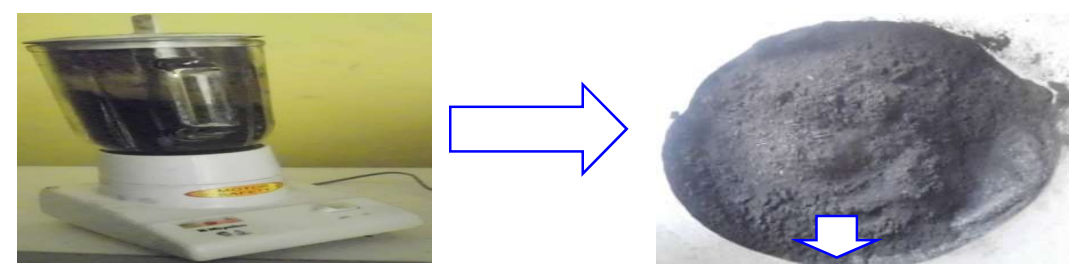


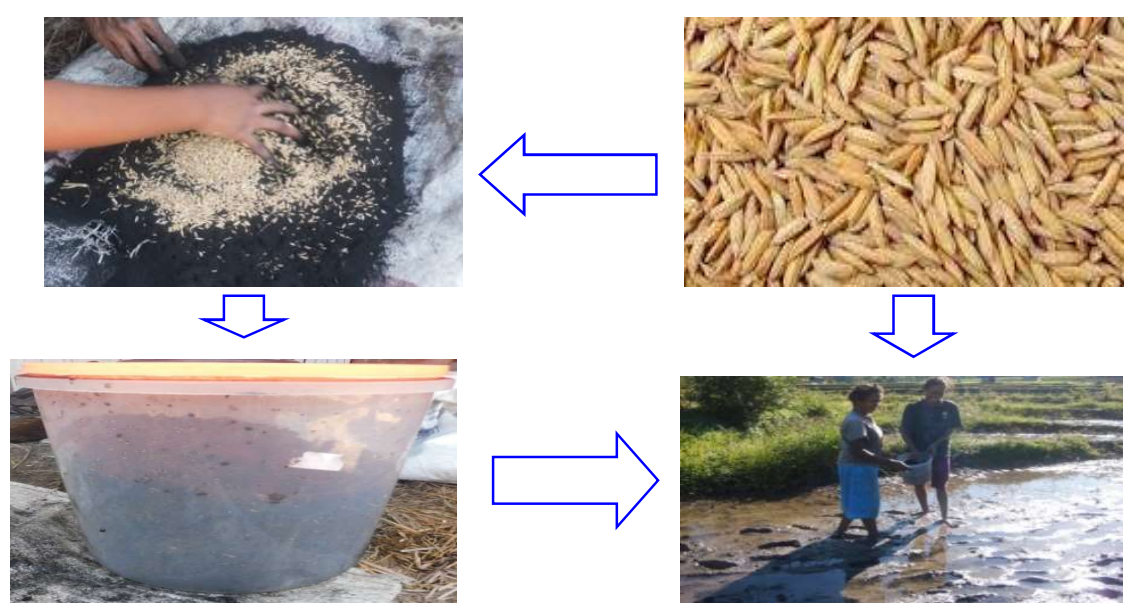

Gambar 1: Bagan Alir Kegiatan Pengabdian

\section{HASIL DAN PEMBAHASAN}

Animo masyarakat dalam mengikuti pelatihan sangat tinggi. Anggota kelompok tani terdiri dari berbagai suku yang ada di Desa Noepesu (Gambar 2). Setelah pelatihan berlangsung, petani langsung mempraktekkan persemaian benih yang sudah diinvigorasi dilahan sawah mereka (Gambar 3). Perlakuan invigorasi benih dapat meningkatkan aktivitas enzim amilase dan dehidrogenase serta memperbaiki integritas membran. Enzim tersebut membantu memperbaiki organel sel penting yang mengalami kerusakan. Aktivitas enzim amilase dan dehidrogenase menunjukkan daya hidup benih). Beberapa jenis enzim yang erat kaitannya dengan perbaikan membran seperti ATPase, ACC sintetase dan isocitrate lyse meningkat selama perlakuan invigorasi. Perubahan komposisi lemak membran akibat aktivitas enzim tersebut menyebabkan meningkatnya integritas membran sehingga mengurangi kebocoran metabolik (Sutariati et al., 2014). Hasil penelitian Koes dan Arief (2011), perlakuan matriconditioning menggunakan abu sekam, serbuk gergaji dan jerami padi pada benih jagung yang telah disimpan selama 8 bulan memberikan daya berkecambah yang lebih tinggi dibanding dengan tanpa pemberian matriconditioning. 

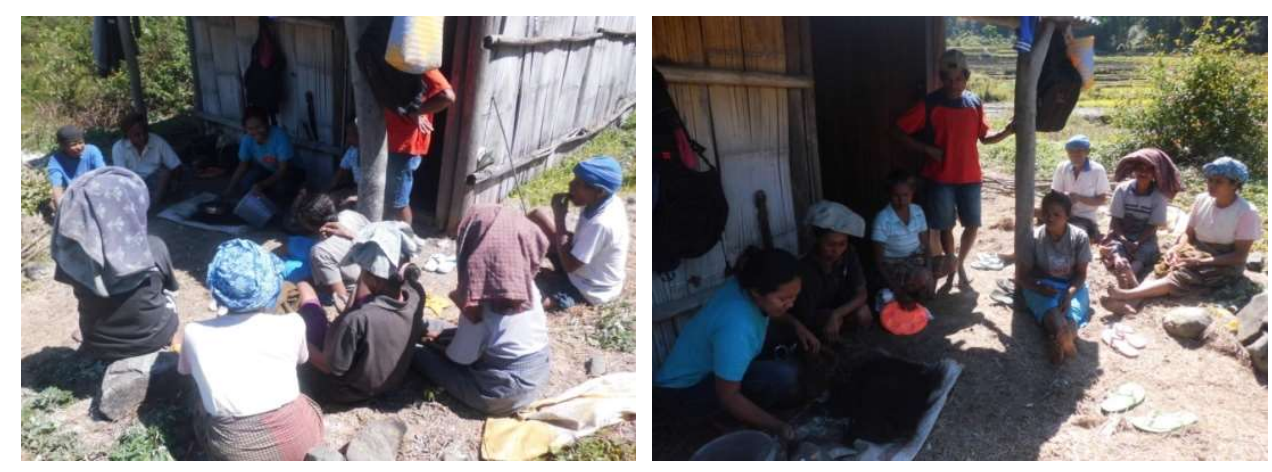

Gambar 2: Animo Kelompok Tani untuk Mengikuti Kegiatan Pelatihan Metode Invigorasi pada Benih Padi di Lahan Sawah Petani di Desa Noepesu

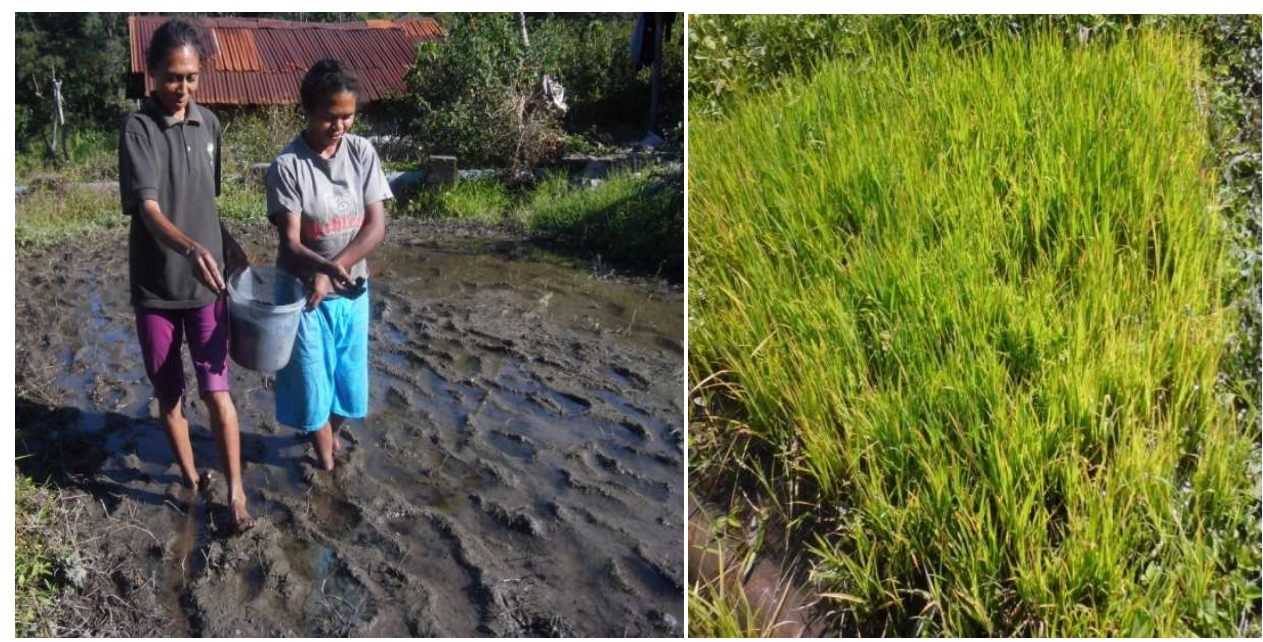

Gambar 3: Persemaian dan Pertumbuhan Semai Padi di Lahan Sawah

Matriconditioning dapat diintegrasikan dengan zat pengatur tumbuh, atau pestisida, biopestisida, dan mikroba bermanfaat (Ilyas, 2006). Hasil penelitian Yullianida (2004) terhadap bunga matahari menunjukkan bahwa perlakuan invigorasi dengan air maupun larutan antioksidan efektif meningkatkan potesi tumbuh maksimum, daya berkecambah dan kecepatan tumbuh relatif serta nilai daya hantar listrik. Haris et al., (2001) menyatakan bahwa benih padi yang diberi perlakuan invigorasi dapat memberikan keuntungan meliputi perkembangan dan keseragaman benih yang lebih cepat, tanaman menjadi lebih vigor dan tahan terhadap kekeringan, serta pembungaan dan panen yang lebih cepat dan meningkatkan hasil panen menjadi lebih tinggi. Produksi benih yang kurang optimal, teknik penanganan pascapanen dan teknik penyimpanan yang kurang baik dapat menyebabkan kemunduran benih yang berdampak terhadap penurunan daya berkecambah (Copeland dan Mc. Donald, 2001). Invigorasi merupakan suatu cara untuk meningkatkan mutu fisiologis benih, terutama 
vigor benih, melalui perlakuan fisik maupun kimiawi. Benih yang bervigor tinggi mampu menunjukkan kinerja yang baik dalam proses perkecambahan dalam kondisi lingkungan yang seragam. Hasil pengabdian invigorasi pada benih padi menunjukkan bahwa perlakuan invigorasi sebelum ditanam mampu meningkatkan daya tumbuh benih di lapangan. Hal ini sesuai hasil penelitian De et al., (2003) bahwa invigorasi pada benih gandum sebelum ditanam dapat meningkatkan daya tumbuh di lapangan.

Selama proses invigorasi berlangsung, terjadi peningkatan aktivitas metabolisme dalam benih sehingga benih yang diberi perlakuan invigorasi akan lebih cepat berkecambah. Teknik invigorasi benih adalah perlakuan pada benih (seed conditioning) yang bertujuan untuk mempercepat dan menyeragamkan pertumbuhan serta meningkatkan persentase pemunculan kecambah dan bibit. Prinsipnya adalah memobilisasi sumber daya yang dimiliki benih (internal) ditambah sumberdaya dari luar (eksternal) untuk memaksimumkan perbaikan pertumbuhan dan hasil tanaman. Seed conditioning merupakan perbaikan fisiologis dan biokimiawi yang berhubungan dengan kecepatan dan keserempakan, perbaikan dan peningkatan potensial perkecambahan dalam benih selama penundaan perkecamabahan oleh media potensial matriks rendah (matriconditioning) atau oleh media berpotensial osmotik rendah (priming atau osmoconditioning). Penggunaan teknik invigorasi benih terbukti efektif meningkatkan viabilitas dan vigor benih (llyas et al., 2002). Ruliyansyah (2011) melaporkan bahwa invigorasi benih dengan integrasi matriconditioning arang sekam maupun serbuk gergaji memulihkan atau mengurangi kebocoran sel ketika proses imbibisi berlangsung dan mengurangi perubahan metabolik selama perkecambahan.

Perlakuan invigorasi menggunakan arang sekam dalam pengabdian ini, imbibisinya berjalan sangat lambat karena terjadinya kekurangan air. Mariska (2006) menyatakan bahwa perkecambahan akan terjadi apabila kandungan air tercukupi. Apabila benih mengalami kekurangan air maka metabolisme yang semula aktif menjadi terhenti. Perkecambahan yang terjadi karena adanya aktivitas metabolisme. Dengan demikian, apabila ada kecaman air pada saat benih berkecambah maka metabolisme benih terganggu akibat air yang diperlukan tidak cukup. Menurut Utomo (2006), air mutlak diperlukan untuk perkecambahan meskipun demikian, perendaqman yang yang terlalu lama dapat menyebabkan anoksia (kehilangan oksigen), sehingga membatasi proses respirasi. Rusmin (2004) menyatakan proses imbibisi yang lebih cepat akan mengakibatkan proses berikutnya terjadi lebih awal, seperti pecahnya kulit benih, 
pengaktifan enzim dan hormon, perombakan cadangan makanan, translokasi nutrisi dan keluarnya radikula.

\section{SIMPULAN}

Benih padi yang disimpan dalam jangka waktu lama akan mengalami penurunan viabilitas jika ditanam kembali sehingga akan merugikan petani. Teknik invigorasi pada benih padi sebelum disemai merupakan salah satu cara untuk meningkatkan viabilitas benih yang sudah disimpan lama, meskipun secara individu benih, sudah terjadi deteriorasi. Invigorasi benih dengan teknik matriconditioning dengan perlakuan hidrasi sebelum tanam dapat dikembangkan untuk memperbaiki perkecambahan, pertumbuhan dan produksi tanaman.

\section{UCAPAN TERIMA KASIH}

Kami menyampaikan terima kasih kepada LPPM Universitas Timor yang telah mendanai dan mendukung kegiatan pengabdian ini.

\section{DAFTAR PUSTAKA}

Arief R, Koes F. 2010. "Invigorasi benih". Prosiding Pekan Serealia Nasional. Balai Penelitian Tanaman Serealia. Sulawesi Selatan [internet]. ISBN : 978-979-8940-293. [Waktu dan tempat pertemuan tidak diketahui]. Sulawesi Selatan (ID): Balitsereal. HIm 473-477.

Arif, R., Saenong S. 2006. "Pengaruh Ukuran Biji dan Periode Simpan terhadap Pertumbuhan dan Hasil Jagung". Penelitian Pertanian Tanaman Pangan Vol. 25, No. 1: hlm 52-56.

Copeland, L.O., M. B. Mc. Donald. 2001. Principles of Seed Science and Technology. Boston: Kluser.

De, BK., Mandal, A.K., Basu, R.N. 2003. "Seed Invigoration Treatments on Different Seed Sizes of Wheat (Triticum aestivum, L) for Improved Storability and Field Emergence". Seed Sci and Techno. 31(2):379-388.

Harris, D., A. K. Pathan., P. Gothkar., A. Joshi., W. Chivasa., P. Nyamudeza. 2001. "Onfarm Seed Priming Using Participatory Methods to Rerive and Refine A Key Technology". Agricultural System. 69: 151-164. 
Ilyas S., Sutariati GAK., Suwarno FC., Sudarsono. 2002. "Matriconditioning Improved Quality and Protein Level of Medium Vigor Hot Pepper Seed". Seed Technol. 24:65-75.

Ilyas S. 2006. Seed Treatment Using Matriconditioning to Improve Vegetable Seed quality.

Ilyas S. 2012. IImu dan Teknologi Benih: Teori dan Hasil-Hasil Penelitian. Bogor: IPB Press. $138 \mathrm{p}$.

Khan AA. 1992. "Preplant Physiological Seed Conditioning". Di dalam: Janick J, editor. Horticultural Reviews. New York (US): Wiley and Sons. HIm 131-181.

Koes, F., Arif R. 2011. "Pengaruh Perlakuan Matriconditioning terhadap Viabilitas dan Vigor Benih Jagung". Seminar Nasional Serealia. HIm 548-555.

Mariska, I. 2006. "Identifikasi Somaklon Padi Gajah Mungkur, Towuti dan IR 64 Tahan Kekeringan Menggunakan Polyethylene Glycol". Balai Besar Penelitian Bioteknologi dan Sumber Daya Genetik Pertanian : Bogor. Bul. Agron. (34) (2); 71 78.

Robi'in. 2007. "Perbedaan bahan kemasan dan periode simpan dan pengaruhnya terhadap kadar air benih jagung dalam ruang simpan terbuka". Buletin Teknik Pertanian, 12 (1):81-91.

Ruliyansyah, A. 2011. "Peningkatan Performa Benih Kacang-Kacangan dengan Perlakuan Invigorasi". Jurnal Tek. Perkebunan dan PSDL vol 1:13-18.

Rusmin, D. 2004. Peningkatan viabilitas benih jambu mete (Anacardium occidentale, L) melalui invigorasi. Balai Penelitian Tanaman Obat dan Aromatik.

Sadjad, S. 1993. Dari Benih Kepada Benih. Jakarta: PT Grasindo.

Sadjad S., Murniati E., llyas S. 1999. Parameter Pengujian Vigor Benih dari Kompratif ke Simultif. Grasindo PT Sang Hyang Seri : Jakarta.

Sutariati, G.A.K., Zul'aiza, Darsan, S., Kasra, LD.M.A., Wangadi, S. Mudi, L. 2014. "Invigorasi Benih Padi Gogo Lokal untuk Meningkatkan Vigor dan Mengatasi Permasalahan Dormansi Fisiologis Pascapanen".

Taylor AG, Allen PS, Bennett MA, Bradford KJ, Burris JS, Misra MK. 1998. Seed enhancements. Seed Science Research. 8(2):245-256.

Utomo, B. 2006. Ekologi Benih. Medan: karya ilmiah Universitas Sumatera Utara.

Yullianida. 2004. Pengaruh Antioksidan sebagai Perlakuan Invigorasi Benih sebelum Simpan terhadap Daya Simpan Benih Bunga Matahari (Helianthus annuus L.) Skripsi. Fakultas Pertanian. IPB. Bogor. 40 hal. 